\title{
Retraction Note to: Application of gene expression programming to predict the compressive damage of lightweight aluminosilicate geopolymer
}

\author{
Ali Nazari ${ }^{1}$ \\ Published online: 15 April 2020 \\ (c) Springer-Verlag London Ltd., part of Springer Nature 2020
}

Retraction Note to: Neural Comput \& Applic (2019) 31 (Suppl 2):S767-S776

https://doi.org/10.1007/s00521-012-1137-5

The Editor-in-Chief has retracted this article [1] because it significantly overlaps with a number of articles including those that were under consideration at the same time $[2,3]$ and previously published articles [4-6]. Additionally, the article shows evidence of peer review manipulation. The author has not responded to any correspondence regarding this retraction.

\section{References}

1. Nazari A (2019) Application of gene expression programming to predict the compressive damage of lightweight aluminosilicate geopolymer. Neural Comput Appl 31:767-776. https://doi.org/10. 1007/s00521-012-1137-5

2. Nazari A (2019) Predicting the total specific pore volume of geopolymers produced from waste ashes by gene expression

programming. Neural Comput Appl 31:751-757. https://doi.org/ 10.1007/s00521-012-1135-7

3. Nazari A, Riahi S (2013) Predicting the effects of nanoparticles on compressive strength of ash-based geopolymers by gene expression programming. Neural Comput Appl 23:1677-1685. https:// doi.org/10.1007/s00521-012-1127-7

4. Nazari A, Riahi S, Khalaj G, Bohlooli H, Kaykha MM (2012) Retracted: Prediction of compressive strength of geopolymers with seeded fly ash and rice husk-bark ash by gene expression programming. Int J Damage Mech 21(8):1202-1226. https://doi. org/10.1177/1056789511431991

5. Nazari A (2012) Experimental study and computer-aided prediction of percentage of water absorption of geopolymers produced by waste fly ash and rice husk bark ash. Int $\mathrm{J}$ Miner Process 110-111:74-81. https://doi.org/10.1016/j.minpro.2012.04.007

6. Nazari A (2013) Artificial neural networks application to predict the compressive damage of lightweight geopolymer. Neural Comput Appl 23:507-518. https://doi.org/10.1007/s00521-0120945-y

Publisher's Note Springer Nature remains neutral with regard to jurisdictional claims in published maps and institutional affiliations.
The original article can be found online at https:// doi.org/10.1007/s00521-012-1137-5.

\section{Ali Nazari}

alinazari84@aut.ac.ir

1 Department of Materials Science and Engineering, Saveh Branch, Islamic Azad University, Saveh, Iran 